\title{
Does Portfolio Quality Influence Financial Sustainability? A Case of Microfinance Institutions in Kenya
}

\author{
Stephen K. BITOK*, Josephat Y. CHEBOI**, Ambrose KEMBOI*** \\ Received: September 18, 2019 Revised: November 21, 2019 Accepted: January 05, 2020
}

\begin{abstract}
Purpose: The purpose of this study was to examine the relationship between portfolio quality and financial sustainability of microfinance institutions in Kenya. Research Design, Data, and Methodology: The analysis was based on a panel dataset of 30 microfinance institutions for the period of 2010 to 2018. Data was obtained from the Microfinance information exchange (MIX) database, and it was analyzed through descriptive and inferential statistics with the aid of STATA. Based on the results of the Hausman test, the study adopted the fixed effect regression model to test the research hypothesis. Results: The study found that portfolio quality had a positive significant effect on financial sustainability of Microfinance institutions in Kenya $(\beta=0.211 ; p$-value $<0.05)$. For the control variables; firm age had a positive effect $(\beta=0.773 ; p$-value $<0.05)$, while firm size $(\beta=-0.749$; $p$-value $<0.05)$ had a negative effect on financial sustainability. Conclusions: The study concluded that portfolio quality has an important influence on the financial sustainability of microfinance institution. The study recommends that managers of microfinance institutions should devise good collection policies to improve portfolio quality while lessening loan default rate. The portfolio quality may improve the overall profitability and enhance investor confidence in their strategic decision-making on refinancing.
\end{abstract}

Keywords: Portfolio quality, Financial Sustainability, Microfinance institutions, institutional theory.

JEL classification Code: G20, G21, G29, G32, O16

\section{Introduction}

Microfinance institutions envisage offering financial services to underprivileged people who are excluded from formal banking services (Nyamsogoro, 2010). The microfinance movement is accredited to the pioneering work of Mohammed Yunus's model, Grameen Bank, in a poverty-stricken village in Bangladesh (Yunus, 2007) and the subsequent Nobel Peace Award in 2006, which drew global attention (Knewtson \& Qi, 2019). This has resulted into expanded practice across the globe, presenting diverse tools for achieving economic development (Lopatta, Jaeschke, \& Chen, 2017). Specifically, microfinance

${ }^{*}$ Corresponding Author, Professor, Department of Accounting \& Finance, Moi University, Eldoret 1931-30100, Kenya. Email: stephenkbitok@gmail.com

**PhD, Department of Accounting \& Finance, Moi University, Eldoret 3900-30100, Kenya. Email: cheboijos@gmail.com

${ }^{* * *} \mathrm{PhD}$, Department of Management Science, Moi University, Eldoret 3900-30100, Kenya. Email: amkei2003@yahoo.com ๑ Copyright: Korean Distribution Science Association (KODISA)

This is an Open Access article distributed under the terms of the Creative Commons Attribution NonCommercial License (https://creativecommons.org/licenses/by-nc/4.0/) which permits unrestricted noncommercial use, distribution, and reproduction in any medium, provided the original work is properly cited. institutions (MFIs) have contributed substantially to socioeconomic welfare in developing economies, that are characterized by high unemployment and underdeveloped financial markets (Abdulai \& Tewari, 2017). Due to their social impact on entrepreneurial activities among the unbanked population, MFIs' financial sustainability is vital in safeguarding their future beyond reliance on donor funds, in addition to their long-term success (Chakravarty \& Pylypiv, 2015; Knewtson \& Qi, 2019).

Financial sustainability refers to the likelihood that a business is self-sufficient without any external support (Iezza, 2010). In the context of this study, financial sustainability denotes the ability of MFIs to finance present and future spending commitments within their means (Kinde, 2012; Wijesiri et al., 2017). Considering that the concept of MFIs is at its nascent stage, and the low volume of customer savings, these firms are mainly financed by government subsidies and donors fund (Nawaz, 2010). Similarly, extant literature depicts MFIs as unsustainable implying that they continue to grapple with worsening portfolio quality (Abraham \& Balogun, 2012). Also, microfinance institutions charge inflated interest rates, compared to commercial banks, thus denying credit to the poor; who MFIs intend to serve (Collett, 2015). Besides, 
researchers suggest that overreliance on donor fund may pose a serious threat to MFIs revenue model, and ultimately financial sustainability (De Aghion, Armendáriz, \& Morduch, 2007; Nawaz, 2010).

Recent studies show that microfinance institutions are grappling with financial sustainability owing to increased monitoring costs, competition and growing nonperforming loans. Unlike conventional banks, that have advanced mechanisms of appraising and monitoring borrowers, MFIs have a poor understanding of borrowers' default risk thus suffers from lower portfolio quality (Knewtson \& Qi, 2019). Furthermore, maintaining good portfolio quality is essential for sustained delivery of microfinance services, poor quality of loan portfolio leads to losses which makes making it difficult for MFIs to sustain their operations.

Portfolio quality, also referred to as portfolio at risk, is a measures of the share of MFI's outstanding loan portfolio with more than 30days in arrears (Ayayi \& Sene, 2010). Portfolio quality is important because loan portfolio is the key source of risk to institutions engaging in financial intermediation. According to Hermes and Lensink (2007), portfolio quality is part of asset management that put emphasis on decision making by the management. If loan portfolio quality deteriorates, this might lead to financial unsustainability and eventually the collapse of MFIs. Thus, MFIs ought to focus more on their portfolio quality which translates to financial sustainability. In view of the connection between portfolio quality and MFIs financial sustainability, a few researchers have devoted substantial effort to find out the causal relationship; one branch of studies posit a positive causality (Adongo \& Stork, 2006) while the other a negative relationship (Bayai \& Ikhide, 2018; Tehulu, 2013) which can be explained by contextual and methodological issues. For instance, Nyamsogoro (2010) used a sample 98 Tanzanian MFIs and fixed effect regression reported a positive relationship, Bayai (2008) who considered a sample of 68 MFI's in the SADC region, probit and logit, found a negative relationship. Based on the aforementioned, the relationship between portfolio quality and financial sustainability of MFIs is inconclusive, therefore, requires further scrutiny. Therefore, our present study seeks to fill the gap by investigating the influence of portfolio quality on MFIs financial sustainability in Kenya using the Generalized Method of Moments (GMM).

\section{Literature Review}

\subsection{Theoretical Literature: Institutional Theory}

This study explores the influence of portfolio quality on MFIs sustainability. According to (Meyer \& Rowan, 1977) seminar paper "Institutionalized organizations: Formal structure as myth and ceremony", institutions are confronted by pressure arising from areas other than task environments. Having well-established strategies, structures or framework and practice in various professions, policies, and programs. Microfinance institutions must integrate their products, services, techniques, policies, and programs to achieve well-balanced results. The institutions are faced with challenges arising from environmental pressure which managers have to navigate. These managers are constrained by socially derived norms and expectations that assume the organizational environment and the desired conduct. Champions of financial sustainability suggest that MFI should be able to cover costs with revenue collected (Brau $\&$ Woller, 2004). The theory offers insight into the continuity and conformity of microfinance institution practices through an appreciation of organizational-level processes (Delbridge \& Edwards, 2007). Apart from MFIs improving their structures, they should also align them to the institutional framework to achieve legitimacy, resources, stability and better survival chances in the sector.

Traditionally, the theory is equally concerned with the organizational ability to conform to the market dynamics (DiMaggio \& Powell, 1983; Meyer \& Rowan, 1991; Scott, 2008). The Theory also influences firm's approaches on social, political and economic practices (Jennings \& Zandbergen, 1995; North, 1990). Deviations in social values, technological advancements and regulations sway the decisions on financial sustainability (Ball \& Craig, 2010; Lounsbury, 1997; Rivera, 2004). The institutional view has allowed an extra focus on the importance of conformity, regulatory and social pressures in dynamic organizational actions (Westphal, Gulati, \& Shortell, 1997). Scholars have focused mainly on MFI sustainability (Woller, Dunford, \& Woodworth, 1999), they also observed that financial inclusion remains the core objective of microfinance institutions. Consequently, inclusion confirms the establishment of sustainable financial intermediation.

\subsection{Empirical Review}

\subsubsection{Portfolio Quality and Financial Sustainability}

A firm's long-term growth and survive is dependent on its financial sustainability. This is so, particularly to MFIs that lend to clients who are viewed as un-bankable, that is high risk borrower. Therefore, MFIs must devise lending techniques that locks out questionable borrowers to avert the risk of default, which could accelerate the deterioration rate of the portfolios hence eroding financial sustainability (Schreiner, 2003). Portfolio quality is an indicator of the ability to recover the principal amount and generate interest. It is mainly determined by the portfolio at risk (Ayayi \& Sene, 2010).

This studies showed that interest earned from loans 
serves as the main source of income to MFIs (Fernando, 2006; Tellis \& Seymour, 2002). The amount of interest earned from loans can determine the portfolio quality. Further, the loan principal and interest repayment performance are among other indicators (Godquin, 2004). The management of portfolios remains a crucial activity on a daily basis. It is believed that the longer the loan repayment period, the greater the risk; which is known as a portfolio at risk. CGAP (2003) defines portfolio quality as, an outstanding amount loan premium due by a certain number of days. The portfolio quality of loan has also been described by the rate of the portfolio at risk, at a specified number of days, divided by gross loan portfolio. Higher portfolio at risk indicates poor collection policy, and MFI inefficiency in making the collection (De Aghion et al., 2007).

The main clients of MFIs are financially excluded individuals and micro-enterprises that lack necessary collaterals or reliable financial and accounting information to secure credit. Screening to distinguishing between microentrepreneurs and individuals without bias plays a critical role in MFIs sustainability and also hinders the repayment rates (Chowdhury, 2007). Most MFIs apply progressive loans to enhance repayment. Borrowers aim at accessing adequate finance to achieve individual or enterprise growth and to advance their social wellbeing (Schreiner, 2003). Furthermore, the most common credit management tools used by the sector include incentives for repayments, group lending and credit scores (Ibtissem \& Bouri, 2013; Viswanathan \& Shanthi, 2017). In the recent past, a study by Gibbons and Meehan (1999) highlighted use of dynamic loans and risk management methods like pre-default which is based on the possibilities of staggering the repayment of microcredit. Portfolio quality contributes to the MFI sustainability, such that, the greater the risk, the more inefficient the MFIs, therefore, less financially sustainable (Nyamsogoro, 2010).

The relationship between portfolio quality and MFIs financial sustainability has elicited a lot of research interest among scholars and practitioners, though, their findings are largely debatable. Using unbalanced panel data drawn from 23 microfinance institutions (MFIs) in East Africa from the period 2004 to 2009, Tehulu (2013) found that portfolio quality had a negative and significant effect on financial sustainability of MFIs in Ethiopia. Conversely, Ayayi (2010), who examined the relationship between portfolio quality and financial sustainability with data representing a sample of 101 countries, for period over 1998-2006, the study found that portfolio quality had a positive effect on financial sustainability. 379 MFIs in71 countries for 6 years-from 2003 to 2008. From a similar perspective, Nyamsogoro (2010) investigated the portfolio quality and financial sustainability causality in Tanzania.
The study used a panel data set of four years drawn from a sample of 98 microfinance institutions. The findings of the study revealed that portfolio quality had a positive effect on performance. Based on the existing literature the study hypothesizes as follows;

Ho: Portfolio quality has no significant influence on MFIs financial sustainability in Kenya.

\section{Research Design}

A research design specifies the plan on collection and data exploration with the intention of combining relevant information for research purpose and procedure. The study adopted an explanatory research design that is quantitative and hypotheses tested by measuring the association between variables using statistical techniques. Further, the study also employed the use of panel data regression model.

\subsection{Target Population and Dataset}

The target population were all the 52 registered microfinance institutions in Kenya for period 2010-2018. Only 30 MFIs qualified for the study due to their substantial information. Secondary data from the Microfinance Information Exchange (MIX) database on portfolio ratios was extracted using a data collection schedule. The data encompassed panel data which consisted of time series and cross-sections, it was then analyzed using descriptive statistics. Hypotheses were tested using multiple regression analysis. F-statistics was used to test fixed and random effects. Hausman test showed that fixed effect model was the best to explain the association between the variables.

\subsection{Research Model}

The objective of the study is to establish the effect of portfolio quality of financial sustainability therefore the study had 3 sets of variables. The dependent variable (financial sustainability), which was measured the adjusted operating revenue/adjusted (financial expense + loan loss provision expense + operating expense) (Yaron \& Manos, 2007; Henock, 2019). the independent variable (portfolio quality) the study measures portfolio quality by portfolio at risk beyond 30 days (PAR30) which scholars revealed the potential for future losses based on the current performance (Godquin, 2004; Nyamsogoro, 2010). Control variables (MFI age and MFI size) control variables were employed in order to capture the MFI's heterogeneity. The study used firm-level controls that is; MFIs size and MFIs age. MFIs size was measured by the total amount of money lent by 
MFI (Cull et al., 2007; Bogan, 2012). The larger the MFI is, the more complex it becomes, and the more it adopted formal board composition and mechanisms, that is, monitoring becomes more important and advising less (Strom et al., 2014). The specification of size is the natural logarithm of total assets, which reduces outlier bias. The MFI's age is an important control variable since an MFI is likely to learn management policies and methods employed to achieve profitability thus performance thus achieving financial sustainability (Morduch, 1999; Bhanot \& Bapat, 2015). MFI age was thus measured using the number of years since their incorporation.

Multiple linear regression model was utilized to investigate the effect in the study. The equation is described as follows;

$$
F S_{i t}=\beta_{0}+\beta_{1} \text { MFIAge }+\beta_{2} \text { MFISize }+\beta_{3} Q L P+\varepsilon
$$

Model.

Where:

$\mathrm{FS}_{\text {it }}=$ Financial sustainability for MFI $\mathrm{i}$ in year $\mathrm{t}$

$\mathrm{QLP}_{\mathrm{it}}=$ Portfolio quality for MFI $\mathrm{i}$ in year $\mathrm{t}$

MFISize $_{i t}=$ Size for MFI $i$ in year $t$

MFIAge $_{\mathrm{it}}=$ Age for MFI $\mathrm{i}$ in year $\mathrm{t}$

$\alpha 0$ it $=$ constant

$\beta_{1 \text { it }}-\beta_{3 i t}=$ coefficients of the regression

$\varepsilon_{\text {it }}=$ error terms

$\mathrm{i}=$ MFIs (cross-section dimensions) ranging from 1 to 30

$\mathrm{t}=$ Time (time-series dimensions) ranging from 2010 to 2018

\subsection{Panel Unit Root Tests}

Table 1: Unit root test

\begin{tabular}{|c|c|c|c|c|}
\hline & $\begin{array}{c}\text { Inverse } \\
\text { chi- } \\
\text { squared } \\
\mathbf{( 5 8 )}\end{array}$ & $\begin{array}{c}\text { Inverse } \\
\text { normal }\end{array}$ & $\begin{array}{c}\text { Inverse } \\
\text { Logitt } \\
\mathbf{( 1 4 4 )}\end{array}$ & $\begin{array}{c}\text { Modified } \\
\text { inv. chi- } \\
\text { squared }\end{array}$ \\
\hline $\begin{array}{c}\text { P } \\
\text { Financial } \\
\text { Sustainability }\end{array}$ & 155.46 & -3.52 & -6.31 & 1.15 \\
\hline p-value & .00 & .00 & .00 & .00 \\
\hline $\begin{array}{c}\text { Portfolio } \\
\text { Quality }\end{array}$ & 88.21 & -1.89 & -4.17 & 5.04 \\
\hline p-value & .00 & .03 & .00 & .00 \\
\hline Firm age & 52.28 & .39 & .14 & -.71 \\
\hline p-value & .00 & .00 & .00 & .00 \\
\hline Firm size & 215.27 & -5.36 & -8.84 & 14.60 \\
\hline p-value & .00 & .00 & .00 & .00 \\
\hline
\end{tabular}

Source: Research Author (2019)

The study tested for unit root to establish if the variables were stationary, which is the fundamental assumption of multiple regression analysis. Panel data is said to be stationary if the mean and variance are constant over time
(Gujarati, 2004). Non-stationary data leads to a spurious relationship. This study tested unit root using Fisher, Phillips and Peru test. Conventionally, unit root tests are premised on the following hypothesis.

Null hypothesis (Ho): All panels contain a unit root.

The alternative hypothesis (H1): At least one panel is stationary.

Looking at the p-values in Table 1, the null hypothesis was rejected at all conventional significance levels for all the variables of the study, which implied that there was no unit root in the data hence resulting to the independence of means and variances in the data with respect to time.

\subsection{Test for Homoskedasticity}

The study tested homoskedasticity using White test. The findings indicated that Chi2 (35) was 52.47, the p-value of 0.0592 revealing that the null hypothesis was rejected implying that the assumption of homoskedasticity was not violated. The results were tabulated as shown in Table 2 below.

Table 2: White's test for Homoskedasticity

\begin{tabular}{|l|l|l|}
\hline White's & \multicolumn{1}{|c|}{ test for Ho: } & \multicolumn{1}{c|}{ Homoscedasticity } \\
\hline & against Ha: & unrestricted heteroskedasticity \\
\hline & chi2(35) & 52.47 \\
\hline & Prob > chi2 & .0592 \\
\hline
\end{tabular}

Source: Research Author (2019)

\subsection{Test for autocorrelation}

The autocorrelation can be detected using several tests e.g Baltagi-Wu test, Durbin-Watson test and the BreuschGodfrey test. According to Drukker (2003), these tests employ many assumptions such as individual effects types,need for non-stochastic regressors and inability to work with heteroscedasticity. Wooldridge (2002), further argued that the said limitations can also deal with unbalanced panel data with and without gaps in their observations. The null hypothesis of this test showed no first-order autocorrelation existed in the data. The test statistic reported is F-test with one and 7 degrees of freedom and a value of 6.597. The P-value of the F-test was 0.0671 implying that the F-test was not significant at 5\% level. Hence, the hypothesis of first order autocorrelation is supported and the study concludes that residuals are not autocorrelated.

Table 3: Wooldridge test for autocorrelation

\begin{tabular}{|ll|}
\hline Wooldridge test for autocorrelation in panel data \\
\hline $\mathrm{H} 0: \quad$ first-order & autocorrelation \\
\hline $\mathrm{F}(1,7)=$ & 6.597 \\
\hline Prob $>\mathrm{F}=$ & .0671 \\
\hline
\end{tabular}

Source: Research Author (2019) 


\section{Results and Findings}

The tabulation below shows the mean, minimum, maximum and standard deviation of the various variables as used in the model for the period between 2010 and 2018 . Based on table 4, financial sustainability mean was .351 with a minimum of -.864 , maximum of 4.914 and a standard deviation .931. Whereas, portfolio quality mean was -2.63 with a minimum of -6.91 and a maximum of 2.85 . The portfolio standard deviation was 1.39 indicating variability over some time.

Table 4: Descriptive Statistics

\begin{tabular}{|c|c|c|c|c|}
\hline Stats & Financial sustainability & Portfolio quality & MFI age & MFI size \\
\hline Obs & 270 & 270 & 270 & 270 \\
\hline Mean & .3510406 & -2.627456 & .7361932 & 1.864539 \\
\hline Min & -.8639017 & -6.907755 & 0 & 1.145381 \\
\hline Max & 4.914847 & 2.847312 & 1.098612 & 2.236006 \\
\hline Sd & .9310606 & 1.386567 & .4573407 & .1809601 \\
\hline variance & .8668739 & 1.922568 & .2091605 & .0327465 \\
\hline skewness & 2.995655 & .6083031 & -.7924614 & -.6592766 \\
\hline Kurtosis & 13.77088 & 7.196693 & 1.927341 & 3.811311 \\
\hline
\end{tabular}

Source: Research Author (2019)

This study shows the association of variables to test the nature of their statistical relationships. Table 5 illustrates the correlation matrix of the research variables. The correlation between portfolio quality and financial sustainability was $(\mathrm{r}=0.351$, $)$ which depicted a positive significance relationship. While, the correlation between financial sustainability and the control variable were as follows MFI age $(\mathrm{r}=.039, \mathrm{p}<0.05)$ and MFI size $(-.271$, $\mathrm{p}<0.05$ ) respectively.

Table 5: Correlation Matrix Results

\begin{tabular}{|c|c|c|c|c|}
\hline Variables & Fsn & pq & Fa & fs \\
\hline $\begin{array}{c}\text { Financial Sustainabilit } \\
\text { y (Fsn) }\end{array}$ & 1 & & & \\
\hline Portfolio quality (pq) & $.351^{* *}$ & 1 & & \\
\hline Firm age (fa) & $.039^{* *}$ & $.273^{* *}$ & 1 & \\
\hline Firm size (fs) & $-.271^{* *}$ & -.097 & $.459^{* *}$ & 1 \\
\hline
\end{tabular}

**Correlation is significant at the .05 level * Correlation is significa nt at the .01 level

Source: Research Author (2019)

\subsection{Effect of Portfolio quality on Financial Sustainability}

The results for Generalized Method of Moments(GMM) are shown in table 6 below. Unlike the fixed effect regression and the random effect regression GMM is designed for datasets with many panels and few periods. Besides, this estimation model is not affected by strict exogeneity assumption which is common static panel data techniques. Due to the sample size and the nature of the data, 30 MFIs and panel data for the period over 2010-2018, GMM was the most suitable model for testing the research hypothesis. The study's hypothesis stated that; $\mathrm{H}_{\mathrm{o}}$ portfolio quality has no significant effect on MFIs financial sustainability, however, based on the findings this $(\beta=0.12$; $\rho<0.05$ ), the hypothesis was rejected and the study concluded that portfolio quality had a positive and significant effect on MFIs financial sustainability in Kenya.

Table 6: Results for regression analysis (GMM)

\begin{tabular}{|c|c|c|c|c|c|c|}
\hline Financial sustainability & Coef. & Std. Err. & $\mathbf{z}$ & $\mathbf{P}>\mathbf{z}$ & {$[\mathbf{9 5 \%}$ Conf. } & Interval] \\
\hline Financial Sustainability & & & & & & \\
\hline L1. & -.1752311 & .0579629 & -3.02 & 0.003 & -.2888364 & -.0616258 \\
\hline MFI Age & .1623585 & .0570458 & 2.85 & 0.004 & .0505509 & .2741661 \\
\hline Portfolio Quality & .1201611 & .0447626 & 2.68 & 0.007 & .032428 & .2078943 \\
\hline MFI Size & .1114112 & .0232125 & 4.80 & 0.000 & .0659154 & .1569069 \\
\hline Constant & -.7103981 & .1766992 & -4.02 & 0.000 & -1.056722 & -.3640739 \\
\hline
\end{tabular}

The results conform with those of Nyamsogoro (2010) who found that portfolio quality had a positive effect on financial sustainability of MFIs in Tanzania which could be attributed to similarity of contextual factors, Kenya and Tanzania are regarded as developing economies. In support of the above notion, Gibbons and Meehan (1999) noted that the portfolios must be controlled to enhance sustainability of MFIs. In addition, improvement in portfolio returns through employing joint liability strategies result in the realization of financial sustainability (Laffont \& N'guessam 
2000; Cassar et al., 2007). Employing social sanctions that prevents repayment default rate (Ahlin \& Townsend, 2007; Cassar et al., 2007). Therefore, this study argues that portfolio quality is a crucial aspect of financial sustainability. MFIs should strive to manage their risk levels through adopting the best lending policies such; screening of borrowers, training of personnel, proper management of loan portfolios and progressive lending. The study found that MFI size and MFI age had a positive and significant effect on financial sustainability. Size is positively and significantly related to financial sustainability which may be explained by the economies of scale. With age, MFIs improve their financial sustainability because over time MFI benefit from the accumulated assets and larger savings.

\section{Conclusions}

Microfinance institutions play a crucial role in ensuring that the financially excluded and underprivileged individuals and their entities access financial services. Despite its impact to an economy, these institutions continue to grapple with worsening portfolio, which has greatly affected their financial sustainability. It's on this foundation that this study seeks to establish the relationship between portfolio quality and financial sustainability. The study considered 30 MFIs in Kenya using panel data for the period 2010-2018. The findings were positive with a robustly significant relationship. This implies that higher portfolio quality results to more sustainable MFIs. These results also suggested that low default rates lead to better quality of portfolio and improve financial sustainability. Therefore, institutions should exert effort to ensure that they maximize on repayment rates. These finding could be attributed to expansive market access, information sharing, monitoring of portfolio quality, thus impacting positively on financial sustainability.

Business practitioners and shareholders must ensure that MFIs thrive to uphold better portfolios leading to their sustainability through services delivery. Management should craft suitable lending policies to enhance their portfolio through progressive lending, joint liability and make use of information sharing credit bureau (CRB). MFIs should also use of social sanctions to prevent repayment default rates. This article is the first to provide Kenyan empirical evidence on the association between portfolio quality and the financial sustainability. The study findings will be useful to academia and will also provide a reference point for future studies that focus on portfolio quality modeling, especially for small businesses operating in Kenya.

\section{References}

Abdulai, A., \& Tewari, D. D. (2017). Trade-off between outreach and sustainability of microfinance institutions: evidence from sub-Saharan Africa. Enterprise Development and Microfinance, 28(3), 162-181.

Abraham, H., \& Balogun, I. (2012). Contribution of microfinance to GDP in Nigeria: Is there any. International Journal of Business and Social Science, 3(17), 167-176.

Ayayi, A. G., \& Sene, M. (2010). What drives microfinance institution's financial sustainability. The Journal of Developing Areas, 44(1), 303-324.

Ball, A., \& Craig, R. (2010). Using neo-institutionalism to advance social and environmental accounting. Critical Perspectives on Accounting, 21(4), 283-293.

Brau, J. C., \& Woller, G. M. (2004). Microfinance: A comprehensive review of the existing literature. The Journal of Entrepreneurial Finance, 9(1), 1-28.

Chakravarty, S., \& Pylypiv, M. I. (2015). The role of subsidization and organizational status on microfinance borrower repayment rates. World Development, 66, 737748.

Chowdhury, P. R. (2007). Group-lending with sequential financing, contingent renewal and social capital. Journal of Development Economics, 84(1), 487-506.

Collett, K. D. (2015). Proposing a freedom from predatory microfinance lending. Ariz. J. Int'l \& Comp. L., 32, 277.

De Aghion, B. A., Armendáriz, B., \& Morduch, J. (2007). The economics of microfinance. Massachusetts: MIT press.

Delbridge, R., \& Edwards, T. (2007). Reflections on developments in institutional theory: Toward a relational approach. Scandinavian Journal of Management, 23(2), 191-205.

DiMaggio, P. J., \& Powell, W. W. (1983). The iron cage revisited: Institutional isomorphism and collective rationality in organizational fields. American sociological review, 48(2), 147-160.

Drukker, D. M. (2003). Testing for serial correlation in linear panel-data models. The stata journal, 3(2), 168177.

Fernando, N. A. (2006). Understanding and dealing with high interest rates on microcredit: A note to policy makers in the Asia and Pacific region. Retrieved May 22, 2019, from https://think-asia.org/handle/11540/5491

Gibbons, D. S., \& Meehan, J. W. (1999). The microcredit summit's challenge: Working toward institutional financial self-sufficiency while maintaining a commitment to serving the poorest families. Journal of Microfinance/ESR Review, 1(1), 8.

Godquin, M. (2004). Microfinance repayment performance in Bangladesh: How to improve the allocation of loans 
by MFIs. World Development, 32(11), 1909-1926.

Ibtissem, B., \& Bouri, A. (2013). Credit risk management in microfinance: The conceptual framework. $A C R N$ Journal of Finance and Risk Perspectives, 2(1), 9-24.

Iezza, P. (2010). Financial sustainability of microfinance institutions (MFIs): an empirical analysis. Copenhagen Business School Master's Thesis.

Jennings, P. D., \& Zandbergen, P. A. (1995). Ecologically sustainable organizations: An institutional approach. Academy of management review, 20(4), 1015-1052.

Knewtson, H., \& Qi, H. (2019). Managing risk for sustainable microfinance. The Journal of Risk Finance, 20(1), 2-13.

Lopatta, K., Jaeschke, R., \& Chen, C. (2017). Stakeholder engagement and corporate social responsibility (CSR) performance: International evidence. Corporate Social Responsibility and Environmental Management, 24(3), 199-209.

Lounsbury, M. (1997). Exploring the institutional tool kit: The rise of recycling in the US solid waste field. American Behavioral Scientist, 40(4), 465-477.

Meyer, J. W., \& Rowan, B. (1977). Institutionalized organizations: Formal structure as myth and ceremony. American journal of sociology, 83(2), 340-363.

Meyer, J. W., \& Rowan, B. (1991). Institutionalized organizations. and Robert Wuthnow, Meaning and Moral Order. Retrieved May 22, 2019, from https://www.sscnet.ucla.edu/comm/steen/cogweb/Abstr acts/DiMaggio_97.html

Nawaz, A. (2010). Performance of microfinance: the role of subsidies. Savings and Development, 34, 97-138.

North, D. (1990). Institutions and their consequences for economic performance. In K. Cook \& M. Levi (Eds.), The limits of rationality (pp. 383-401). Chicago:
University of Chicago Press

Nyamsogoro, G. D. (2010). Financial sustainability of rural microfinance institutions (MFIs) in Tanzania. University of Greenwich.

Rivera, J. (2004). Institutional pressures and voluntary environmental behavior in developing countries: Evidence from the Costa Rican hotel industry. Society and Natural Resources, 17(9), 779-797.

Schreiner, M. (2003). Scoring Drop-Out at a Microlender in Bolivia. Savings and Development, 27(2), 101-118.

Scott, W. R. (2008). Institutions and organizations: Ideas and interests $\left(3^{\text {rd }}\right.$ ed.). Los Angeles : Sage Publications.

Tellis, W., \& Seymour, A. (2002). Transition from a Microfinance Institution to Regulated Bank: Technology Infrastructure Planning in a Developing Country, Fairfield University, Fairfield, CT, USA. Retrieved from hyyp://proceedings.informingscience. org/IS2002Proceedings/papers/telli211tr ans.pdf

Viswanathan, P., \& Shanthi, S. (2017). Modelling Credit Default in Microfinance-An Indian Case Study. Journal of Emerging Market Finance, 16(3), 246-258.

Westphal, J. D., Gulati, R., \& Shortell, S. M. (1997). Customization or conformity? An institutional and network perspective on the content and consequences of TQM adoption. Administrative science quarterly, 42(2), 366-394.

Woller, G. M., Dunford, C., \& Woodworth, W. (1999). Where to microfinance. International Journal of Economic Development, 1(1), 29-64.

Yunus, M. (2007). Banker to the poor: Micro-lending and the battle against world poverty. New York: Public Affairs. 